\title{
GAMBARAN PENGETAHUAN DAN PERILAKU 5 MOMEN CUCI TANGAN DALAM PRAKTIK KEBIDANAN PADA MAHASISWA KEBIDANAN POLTEKKES KEMENKES SEMARANG
}

\author{
Indira Ega Octami Nasution ${ }^{1}$, Sri Seriasih², Triana Sri Hardjanti ${ }^{3}$
}

Departement of Midwifery, Poltekkes Kemenkes Semarang, Indonesia

\begin{abstract}
The number of nosocomial infections continues to increase, reaching around $9 \%$ or more than 1.4 million hospitalized patients in hospitals worldwide. One of the effective prevention efforts to break the chain of infection transmission is the five moment hand hygiene. However, there is no research on the knowledge and behavior of five moment hand hygiene among midwifery students in Indonesia. The purpose of this study was to describe the knowledge and behavior of the five moment hand hygiene in midwifery practice among the students of the Poltekkes of the Ministry of Health, Semarang, class of 2017.

This research is a descriptive quantitative study with a cross-sectional approach. The sampling technique used was total sampling with 47 midwifery students. Data were collected using a knowledge questionnaire that had been expertly tested by a lecturer in the Basic Skills of Midwifery, Drs, Ngadiyono, SKp., Ns., M.H.Kes. Data analysis using univariate analysis.

The results showed that the level of knowledge of the midwifery students of the Poltekkes Kemenkes Semarang in the good category was $74.5 \%$ and the behavior in the good category was $100 \%$. The conclusion of this research is that the level of student knowledge and student behavior is in good category. It is hoped that midwifery students from the Health Ministry of Health Semarang will continue to make five moments of hand hygiene a habit when practicing.
\end{abstract}

Keywords : Five moments hand hygiene; nosocomial infection; midwifery students 


\section{PENDAHULUAN}

Hospital-acquired infections (HAls) atau infeksi nosokomial adalah infeksi yang terjadi di pelayanan kesehatan selama menjalani prosedur perawatan dan tindakan medis setelah $\geq 48$ jam dan pada $\leq 30$ hari setelah berada di luar dari fasilitas kesehatan terkait. HAls merupakan salah satu diantara penyebab meningkatnya morbiditas dan mortalitas pada pasien di rumah sakit (Prasetyo, 2017). Prevalensi infeksi nosokomial lebih dari $40 \%$, angka infeksi nosokomial terus meningkat mencapai sekitar $9 \%$ atau lebih dari 1,4 juta pasien rawat inap di rumah sakit seluruh dunia (Masloman, 2015).

Menjaga kebersihan tangan sangatlah penting dalam pelayanan kesehatan, karena merupakan salah satu faktor yang dapat mengakibatkan terjadinya infeksi pelayanan kesehatan. Menurut Boyce, Larson menjaga kebersihan tangan dengan baik dapat mencegah penularan mikroorganisme dan menurunkan frekuensi infeksi nosokomial. Sebuah penelitian mengungkapkan bahwa dengan mencuci tangan dapat menurunkan sekitar $20 \%-40 \%$ terjadinya infeksi nosokomial.

Five moments for hand hygiene penting dilakukan karena pada setiap melakukan tindakan, seseorang selalu menyentuh atau terkontaminasi oleh benda maupun tubuh pasien sehingga tangan terkontaminasi oleh mikroorganisme yang terdapat pada benda maupun tubuh. Setiap moments cuci tangan dilakukan untuk membersihkan tangan dari terpaparnya mikroorganisme yang dapat menularkan ke semua bagian maupun pasien lainnya.

Penelitian oleh Juliana Kartika Dewi (2017) didapatkan data bahwa pengetahuan responden tentang cuci tangan five moments dalam kategori baik, namun dalam pelaksanaannya masih pada persentase sebanyak $42,5 \%$. Sesuai dengan penelitian oleh $\mathrm{Li}$, et al yang dilakukan pada petugas kesehatan didapatkan moment sebelum kontak dengan pasien memiliki persentase yang paling rendah dibandingkan moment lainnya. Beberapa petugas kesehatan yang memiliki pengalaman kurang berdampak pada praktik cuci tangan yang rendah pula. Hasil yang didapat dari five moments petugas kesehatan selalu melakukan cuci tangan pada moment 1 $(18,5 \%)$ sampai moment $3(48,9 \%)$.

Berdasarkan studi pendahuluan yang peneliti lakukan didapatkan data bahwa masih terdapat mahasiswa yang tidak tahu dan hafal tentang momen cuci tangan. Penerapannya dalam sehari-hari seperti saat praktik pun juga masih terdapat moment yang dilewatkan.

Penerapan five moment hand hygiene merupakan salah satu indikator yang disyaratkan $\mathrm{JCl}$ (Joint Commission International) harus mencapai $100 \%$ bagi seluruh petugas kesehatan yang memberikan asuhan kepada pasien (Putri, 2018). Selain itu, mahasiswa belum 
sepenuhnya melakukan five moment hand hygiene dikarenakan beberapa faktor, dimana hasil wawancara, faktor pengetahuan dan tidak hafal lebih banyak disebutkan oleh mahasiswa yaitu sebanyak enam orang. Berdasarkan data diatas, maka peneliti tertarik untuk melakukan penelitian ini karena di Indonesia sendiri belum dilakukan penelitian terkait five moment hand hygiene pada mahasiswa kebidanan.

\section{METODOLOGI PENELITIAN}

Jenis penelitian adalah desain penelitian deskriptif kuantitatif dengan pendekatan cross sectional karena penelitian ini bertujuan untuk mengetahui gambaran pengetahuan dan perilaku tentang 5 momen cuci tangan atau five moment hand hygiene dalam praktik kebidanan yang telah dilakukan pada mahasiswa kebidanan Poltekkes Kemenkes Semarang, dimana penelitiannya diobservasi sekaligus pada waktu yang sama.

Populasi pada penelitian ini adalah seluruh mahasiswa kebidanan Politeknik $X$ angkatan 2017 yang berjumlah 47 mahasiswa. Tehnik sampel dalam penelitian ini adalah sampel jenuh/total sampling, dimana seluruh populasi menjadi bagian dari sampel yaitu 47 mahasiswa kebidanan Poltekkes Kemenkes Semarang angkatan 2017.

Penelitian dilakukan dengan mengisi kuesioner yang disusun dalam bentuk online menggunakan google form dan disebarkan melalui pesan setelah mendapat persetujuam dan diisi oleh Mahasiswa Kebidanan Poltekkes selaku responden..

\section{HASIL PENELITIAN DAN BAHASAN}

\section{Analisis univariat}

Analisis univariat dalam penelitian ini dilakukan untuk mengetahui karakteristik suatu variabel yang disajikan dalam bentuk tabel distribusi frekuensi.

Tabel 1 Distribusi frekuensi pengetahuan berdasarkan kategori

\begin{tabular}{clll}
\hline & Kategori & $\mathrm{N}$ & $\%$ \\
\hline \multirow{3}{*}{ Pengetahuan } & Baik & 35 & 74,5 \\
\cline { 2 - 4 } & Cukup & 6 & 12,8 \\
\cline { 2 - 4 } & Kurang & 6 & 12,8 \\
\hline \multicolumn{2}{c}{ Total } & 47 & 100 \\
\hline \multicolumn{2}{c}{ Berdasarkan Tabel 1 menunjukkan }
\end{tabular}

bahwa tingkat pengetahuan mahasiswa tentang five moment hand hygiene pada mahasiswa D4 Kebidanan Poltekkes Kemenkes Semarang mayoritas dalam kategori baik yaitu $74,5 \%$, sedangkan didapatkan tingkat pengetahuan five moment hand hygiene dalam kategori cukup sebanyak 12,8\%, dan juga didapatkan pada penelitian ini tingkat pengetahuan five moment hand hygiene kategori kurang sebanyak $12,8 \%$.

Tabel 2 Distribusi frekuensi perilaku berdasarkan kategori

\begin{tabular}{llll}
\hline & Kategori & $\mathrm{N}$ & $\%$ \\
\hline \multirow{2}{*}{ Perilaku } & Baik & 47 & 74,5 \\
\cline { 2 - 4 } & Total & 47 & 100 \\
\hline
\end{tabular}

$$
\text { Berdasarkan tabel } \quad 4.2
$$

menunjukkan bahwa status perilaku five 
moment hand hygiene pada mahasiswa D4 Kebidanan Poltekkes Kemenkes Semarang dalam kategori baik yaitu sebesar $100 \%$.

\section{Pembahasan}

1) Pengetahuan five moment hand hygiene

Berdasarkan hasil penelitian tentang tingkat pengetahuan five moment hand hygiene didapatkan hasil, mayoritas responden berpengetahuan baik sebesar 74,5\%. Pengetahuan menurut Notoadmodjo (2012) merupakan hasil dari tahu dan ini terjadi setelah melalui proses penginderaan tehadap suatu objek. Penginderaan ini terjadi melalui panca indera manusia, yaitu indera penglihatan, pendengaran, penciuman, perasa dan peraba.

$$
\text { Pengetahuan yang dimiliki }
$$
seseorang dipengaruhi oleh beberapa faktor, seperti pendidikan, usia, jenis kelamin, lingkungan, dan sosial ekonomi serta budaya. Pendidikan sangat mempengaruhi seseorang dalam mendapatkan ilmu dan pengetahuan. Semakin tinggi pendidikan seseorang, maka semakin mudah pula mereka menerima informasi sehingga akan menambah pengetahuan yang dimiliki. Menurut Notoadmojo, pengetahuan merupakan domain yang sangat penting dalam membentuk tindakan seseorang ((Notoatmodjo, 2012)

Tingkat pengetahuan kategori baik yang ditemukan pada penelitian ini dikarenakan mahasiswa kebidanan sudah mendapat materi tentang five moment hand hygiene di institusi pendidikan. Mahasiswa kebidanan sebagian besar memiliki tingkat pengetahuan baik karena mahasiswa juga telah mendapatkan materi dari rumah sakit/ puskesmas pada saat menjalani praktik kerja lapangan pada semester sebelumnya. Mahasiswa kebidanan juga telah mendapat materi atau edukasi dari intitusi pendidikan di bidang kesehatan selama kurang lebih 3,5 tahun. Selain itu, beberapa mahasiswa kebidanan juga mempunyai orangtua yang bekerja di bidang kesehatan, dimana dapat menambah wawasan atau materi five moment hand hygiene tambahan dari orang tuanya. Sebagian besar mahasiswa kebidanan yang mempunyai tingkat pengetahuan baik, juga mempunyai sikap atau perilaku yang baik pula.

Banyak faktor yang dapat memengaruhi tingkat pengetahuan seseorang, salah satunya adalah sumber informasi yang diperoleh. Sumber informasi adalah sesuatu yang menjadi perantara dalam menyampaikan informasi yang lebih banyak sehingga dapat memberikan pengetahuan yang luas bagi penerima informasi. Dimana sumber informasi ini dapat diperoleh dari beberapa media seperti media cetak, elektronik, keluarga, teman dan lain-lain (Wirdaningsih, 2020). Pada saat peneliti melakukan studi pendahuluan, mahasiswa mengatakan terdapat beberapa media poster yang ada pada dinding ruangan rumah sakit atau lahan praktik lainnya 
yang ditempati mahasiswa saat menjalani praktik kerja lapangan juga sangat membantu mahasiswa dalam menambah pengetahuannya tentang lima momen cuci tangan.

Hal ini sejalan dengan penelitian yang dilakukan Wulandari, yang menunjukkan bahwa pengetahuan responden dalam kategori baik sebesar $75,9 \%$. Didukung olah penelitian yang dilakukan Wulandari, dimana pengetahuan merupakan elemen yang sangat penting untuk terbentuknya tindakan seseorang. Upaya untuk meningkatkan pengetahuan dengan memberikan kesadaran melalui kegiatan yang disebut penyuluhan kesehatan, sehingga dengan pengetahuan akan menimbulkan sikap yang didasarkan pada kesadaran dan kemauan individu yang bersangkutan. Pengetahuan terus meningkat apabila institusi pendidikan dapat memberikan edukasi atau materi serta pelatihan yang berkesinambungan bagi seluruh karyawan atau mahasiswa pada semua aspek dengan menerapkan five moment hand hygiene (Wulandari, 2017).

Tidak hanya pengetahuan baik, ditemukan pula mahasiswa yang memiliki tingkat pengetahuan dengan kategori cukup sebesar $12,8 \%$ dan kategori kurang sebesar $12,8 \%$. Pengetahuan merupakan hasil stimulus informasi yang diperhatikan dan diingat, informasi dapat berasal dari pendidikan formal dan pendidikan non formal. Pengalaman hidup seseorang, percakapan setiap hari, membaca melihat media cetak, mendengar radio dan menonton TV dapat pula meningkatkan pengetahuan seseorang (Arini, 2020). Pengetahuan mahasiswa yang masih dalam kategori cukup dan kurang, disebabkan oleh beberapa faktor diantaranya sudah mendapat materi dan pendidikan namun lupa. Hal ini dapat disimpulkan bahwa IQ dan stimulus setiap orang berbeda-beda. Pada penelitian ini ditemukan beberapa mahasiswa kebidanan yang menjawab dengan jawaban tidak tepat pada urutan five moment hand hygiene. Hal ini disebabkan karena responden menganggap jika urutan five moment hand hygiene tidak terlalu penting untuk diingat atau diindahkan. Terdapat mahasiswa yang memiliki tingkat pengetahuan kurang tetapi, mempunyai sikap atau perilaku yang baik. Ini disebabkan pada saat mahasiswa menjalani praktik di rumah sakit atau puskesmas, mahasiswa mengikuti teman atau bidan yang sedang praktik bersamanya melakukan kegiatan five moment hand hygiene dengan tepat setiap saat asuhan dan menjadi perilaku kebiasaan.

Penelitian ini sejalan dengan penelitian Elies, menunjukan masih terdapat responden yang memiliki pengetahuan kurang sebesar $64 \%$. Pengetahuan yang masih kurang disebabkan ada beberapa responden yang belum pernah mendapatkan materi atau pelatihan tentang five moment hand 
hygiene,

beberapa

responden

mengatakan pernah mendapatkan

pendidikan dan pelatihan namun lupa.

Kemungkinan lain penyebab kurangnya pengetahuan tentang five moment hand hygiene karena responden masih kurang terpapar dengan informasi tentang five moment hand hygiene (Elies, 2014). Pengetahuan yang dimiliki mahasiswa satu dengan mahasiswa lain berbeda karena setiap rumah sakit atau praktik lahan yang ditempati memiliki fasilitas dan informasi yang berbeda-beda pula (Wulandari, 2017).

2) Perilaku five moment hand hygiene

Penelitian ini juga didapatkan hasil bahwa tingkat perilaku five moment hand hygiene mahasiswa Kebidanan Poltekkes Kemenkes Semarang dalam kategori baik sebesar 100\%. Perilaku adalah suatu bentuk respons atau reaksi bagi stimulus atau rangsangan luar organisme, tetapi saat memberikan respons sangatlah tergantung pada karakteristik atau faktor lain dari orang yang bersangkutan. Artinya, meskipun stimulusnya sama bagi beberapa orang, namun respons setiap orang berbeda Widyawati, (2016).

Tingkat perilaku mahasiswa Kebidanan Poltekkes Kemenkes Semarang dikategorikan baik karena mahasiswa telah mendapatkan materi dari institusi. Mahasiswa kebidanan mayoritas memiliki stimulus atau bentuk respon yang baik pada saat mempraktikan 5 momen cuci tangan. Selain itu, mahasiswa kebidanan juga telah mendapatkan pengalaman praktik kerja lapangan dari awal semester. Terdapat faktor pendidikan yang mempengaruhi perilaku seseorang dimana mahasiswa D4 kebidanan semester 8 sudah menjalani pendidikan selama hampir 4 tahun, yang artinya sudah cukup banyak mendapatkan materi atau edukasi serta praktik lahan secara langsung.

Masa kerja seseorang dapat mempengaruhi pengalaman kerja, semakin lama bekerja diharapkan seseorang memiliki pengalaman kerja semakin banyak pula. Dapat disimpulkan bahwa semakin lama seseorang bekerja maka semakin menguasai ketrampilan yang telah dilakukannya secara berulang setiap harinya dan menjadikan suatu kebiasaan, seperti cuci tangan lima momen.

Hal ini sejalan dan didukung pula dengan penelitian yang dilakukan Wulandari, didapatkan hasil tingkat perilaku baik sebesar $58,6 \%$ dimana mayoritas responden memiliki tingkat perilaku baik, hal ini dikarenakan responden mendapatkan materi dan pelatihan di institusi yang bersangkutan.

Tingkat pendidikan dan pengalaman seseorang yang lebih tinggi dapat mempengaruhi kebiasaan seseorang, semakin lama bekerja/menjalani praktik diharapkan seseorang tersebut memiliki pengalaman semakin banyak pula. Hal ini dapat disimpulkan bahwa semakin lama orang bekerja maka semakin menguasai 
keterampilan yang telah dilakukannya secara berulang kali tiap harinya dan menjadikan hal itu suatu kebiasaan, seperti halnya cuci tangan lima momen (Wulandari, 2017). Begitu juga sama halnya seorang petugas kesehatan yang sudah bekerja akan terfokuskan pada pekerjaannya dimana lebih sering untuk berinteraksi dengan pasien, yang mengharuskan bidan selalu melakukan upaya perlindungan diri, yaitu dengan melaksanakan praktik dalam pencegahan infeksi nosokomial (Puspasari, 2015).

\section{KESIMPULAN}

Berdasarkan hasil yang diperoleh dari penelitian dengan judul gambaran pengetahuan dan perilaku 5 momen cuci tangan dalam praktik kebidanan pada mahasiswa kebidanan Poltekkes Kemenkes Semarang, maka peneliti mengambil kesimpulan sebagai berikut :

a. Mayoritas mahasiswa Kebidanan Poltekkes Kemenkes Semarang telah mempunyai pengetahuan five moment hand hygiene dengan kategori baik sebesar $74,5 \%$.

b. Seluruh mahasiswa Kebidanan Poltekkes Kemenkes Semarang telah mempunyai perilaku five moment hand hygiene dengan kategori baik sebesar $100 \%$.

\section{UCAPAN TERIMAKASIH}

Terimakasih penulis ucapkan kepada seluruh pihak yang terkait dalam penelitian ini. Orangtua yang selalu memberikan dukungan penuh dalam hal apapun. Ibu Sri Setiasih dan Ibu Triana selaku pembimbing yang dengan sabar memberikan bimbingan. Serta temanteman yang terlibat dalam penelitian ini.

\section{DAFTAR PUSTAKA}

1. Dewi, J.K. (2017). Hubungan pengetahuan dengan pelaksanaan cuci tangan five moments perawat di rumah sakit universitas sumatera utara (disertasi). Universitas Sumatera Utara.Arini, M. (2020). BAB II anemia putri Skripsi Universitas Muhammadiyah Semarang. 18, 8-25.

2. Elies Ernawati, A. T. (2014). Penerapan Hand Hygiene Perawat di Rumah Sakit. Jurnal Kedokteran Brawijaya, Vol. 28, Suplemen No. 1.

3. Li, Y., Wang, Y., Yan, D., \& Rao, C. Y. (2016). Self-Reported Hand Hygiene Practices, and Feasibility and Acceptability of Alcohol-Based Hand Rubs Among Village Healthcare Workers in Inner Mongolia, China. Journal Hosp Infect

4. Masloman, A. dkk. (2015). Analisis Pelaksanaan Pencegahan dan Pengendalian Infeksi di Kamar Operasi RSUD Dr Sam Ratulangi Tondano. Jikmu, 5(2), 238-249.

5. Notoatmodjo S. (2012). Promosi kesehatan dan perilaku kesehatan.

6. Notoatmodjo, S. 2010. Metodologi Penelitian Kesehatan. Jakarta: Rineka Cipta

7. Prasetyo, F. D. (2017). Hubungan Pengetahuan dan Sikap Mahasiswa Terhadap Kepatuhan Melakukan Cuci Tangan dengan Metode Hand Wash di IGD RSUD Dr . R . Goeteng Taroenadibrata. Urecol, 445-450. 
8. Puspasari Y. (2015). Hubungan pengetahuan, sikap dengan praktik perawat dalam pencegahan infeksi nosokomial di ruang rawat inap rumah sakit islam Kendal.vJurnal FIKkes J Keperawatan.

9. Putri, F. S. at al. (2018). tingkat Kepatuhan Tenaga Kesehtana Dalama Melakukan Five Moments For Hand Hygine Di Ruang ICU Barata RSUP sanglah Denpasar Tahun 2018. 1, 40-49. 